\title{
The link between the Barents Sea and ENSO events simulated by NEMO model
}

\author{
V. N. Stepanov ${ }^{1}$, H. Zuo ${ }^{1, *}$, and K. Haines ${ }^{1}$ \\ ${ }^{1}$ Dept. of Meteorology, University of Reading, Reading, UK \\ *now at: the European Centre for Medium-Range Weather Forecasts, Reading, UK
}

Correspondence to: V. N. Stepanov (vlnst@hotmail.co.uk)

Received: 25 April 2012 - Published in Ocean Sci. Discuss.: 25 May 2012

Revised: 14 September 2012 - Accepted: 27 October 2012 - Published: 16 November 2012

\begin{abstract}
An analysis of observational data in the Barents Sea along a meridian at $33^{\circ} 30^{\prime} \mathrm{E}$ between $70^{\circ} 30^{\prime}$ and $72^{\circ} 30^{\prime} \mathrm{N}$ has reported a negative correlation between El Niño/La Niña Southern Oscillation (ENSO) events and water temperature in the top $200 \mathrm{~m}$ : the temperature drops about $0.5^{\circ} \mathrm{C}$ during warm ENSO events while during cold ENSO events the top $200 \mathrm{~m}$ layer of the Barents Sea is warmer.

Results from 1 and 1/4-degree global NEMO models show a similar response for the whole Barents Sea. During the strong warm ENSO event in 1997-1998 an anomalous anticyclonic atmospheric circulation over the Barents Sea enhances heat loses, as well as substantially influencing the Barents Sea inflow from the North Atlantic, via changes in ocean currents. Under normal conditions along the Scandinavian peninsula there is a warm current entering the Barents Sea from the North Atlantic, however after the 1997-1998 event this current is weakened.
\end{abstract}

During 1997-1998 the model annual mean temperature in the Barents Sea is decreased by about $0.8^{\circ} \mathrm{C}$, also resulting in a higher sea ice volume. In contrast during the cold ENSO events in 1999-2000 and 2007-2008, the model shows a lower sea ice volume, and higher annual mean temperatures in the upper layer of the Barents Sea of about $0.7^{\circ} \mathrm{C}$.

An analysis of model data shows that the strength of the Atlantic inflow in the Barents Sea is the main cause of heat content variability, and is forced by changing pressure and winds in the North Atlantic. However, surface heat-exchange with the atmosphere provides the means by which the Barents sea heat budget relaxes to normal in the subsequent year after the ENSO events.

\section{Introduction}

Serreze et al. (2007) showed that the Barents Sea, in spite of its small size, is a main reservoir of Arctic Ocean seasonal heat storage: with an area of about $14 \%$ of the Arctic Ocean, more than $50 \%$ of the total arctic heat loss occurs in the Barents Sea. This is because the warm North Atlantic water has a strong influence on the state of the Barents Sea (Mosby, 1962). As a result, a strong heat exchange between the Barents Sea water and the atmosphere is observed: a mean daily heat flux from the Barents Sea to the atmosphere is estimated at $\sim 14 \mathrm{MJ} \mathrm{m}^{-2}$, exceeding similar fluxes in other active regions of the polar seas (The Seas of the USSR, 1990). The warm and relatively saline water entering the Barents Sea from the North Atlantic keeps the subsurface layers warm through into November despite cooling of the surface waters above. The maximum winter mixed layer depth (MLD) in the Barents Sea (normally $\sim 70-100 \mathrm{~m}$, e.g. Signorini and McClain (2009)) can sometimes reach the bottom, i.e. more than $250 \mathrm{~m}$ (e.g. Byshev et al., 2001, 2002) compared to mean Arctic MLD of 30-50 m (Coachman and Aagaard, 1974). The variability of the Atlantic inflow, and the winter MLD due to both convection and Ekman pumping, lead to a very strong variability in the Barents Sea heat storage. It is natural therefore to investigate under what circumstances this variability occurs as the Barents Sea is of high importance in the regional climatic subsystem of the polar region.

A recent analysis of observational data (for nearly a century) in the Barents Sea along a meridian at $33^{\circ} 30^{\prime} \mathrm{E}$ between $70^{\circ} 30^{\prime}$ and $72^{\circ} 30^{\prime} \mathrm{N}$ (Byshev and Neiman, 2000; Byshev and Lebedev, 2000; Byshev et al., 2001; Byshev, 2003) showed negative correlation between ENSO events and water 
temperatures in the top $200 \mathrm{~m}$ : the temperature drops about $0.5^{\circ} \mathrm{C}$ during warm ENSO events while the top $200 \mathrm{~m}$ layer is warmer (also by about $0.5^{\circ} \mathrm{C}$ ) during cold ENSO events (with a high probability $\sim 0.95$ ). Many publications provide evidence of correlations between El Niño events and atmospheric circulations in the Northern Hemisphere (e.g. see Lau et al., 2005; Nicholls et al., 2005; Mokhov and Smirnov, 2006; Müller and Roecker, 2006), as the sea surface temperature anomalies in the tropics can cause a remote teleconnection response in the atmospheric circulation. It is therefore not unrealistic to expect that atmospheric teleconnections during warm ENSO events lead to an anomalous anticyclonic atmospheric circulation pattern (higher atmospheric pressure) developing over the Barents Sea, instead of the more usual cyclonic conditions observed during winter months (e.g. see Byshev and Neiman, 2000; Byshev and Lebedev, 2000; Byshev et al., 2001; Byshev, 2003).

This paper presents the results of a numerical ocean model based synthesis of the changing conditions of circulation and temperatures in the Barents Sea, in the presence of changing atmospheric forcing anomalies. Such a synthesis (or reanalysis) uses a numerical model in combination with available observations to simulate one or more aspects of the Earth system to generate a synthesized estimate of the state of the system (e.g. see http://reanalyses.org/). Section 2 briefly describes the NEMO model and forcing data. Section 3 describes the assimilation method used and the design of the numerical experiments analysed. Section 4 looks at atmospheric circulation over the Barents Sea during cold and warm ENSO events, and the corresponding changes in the model ocean circulation are discussed. Section 5 shows the model relationships/correlations between atmospheric and ocean characteristics, such as atmosphere and ocean temperatures, sea level pressure, and ocean heat content, etc. Section 6 provides conclusions about the link between the atmospheric and ocean processes.

\section{Model description}

The numerical model used is the NEMO coupled ice-ocean model (Madec, 2008) version 2.3, based on the OPA9 code (Madec et al., 1998) and the LIM2.0 sea ice model (Louvain sea Ice Model: Fichefet and Maqueda, 1997; Goosse and Fichefet, 1999). It has a global tri-polar "ORCA" grid with 46 levels in the vertical and either $1^{\circ}$ resolution (ORCA1, as in Smith and Haines, 2009) or $1 / 4^{\circ}$ resolution (ORCA025). These configurations have been developed through the DRAKKAR Consortium (Barnier et al., 2007) and use model parameter settings as defined in (Barnier et al., 2006) and (Penduff et al., 2009). The ORCA025 configuration in particular has $13.8 \mathrm{~km}$ resolution at $60^{\circ} \mathrm{N}$, rising to $6-12 \mathrm{~km}$ in the zonal and $\sim 3 \mathrm{~km}$ in meridional direction in the Arctic. Model bathymetry uses ETOPO2 (US Department of Commerce, 2006), with a 2-min resolution, taking median depths over each model tracer square. The combination of an energy-enstrophy conserving momentum advection scheme, partial bottom cells and free-slip lateral boundary condition have been used as Penduff et al. (2007) shows these improve simulations of the along-shelf flows in the Arctic in ORCA025. Lique et al. (2009 and 2010) and Zuo et al. (2011) have all shown in detailed studies that the ORCA025 model at least performs very well in the Arctic.

Surface atmospheric forcing for the period 1989-2008 is obtained from ECMWF ERAInterim 6-hr reanalysis (Simmons et al., 2007; Dee and Uppala, 2009). The ERAInterim reanalysis provides $10-\mathrm{m}$ wind, $2-\mathrm{m}$ air humidity and temperature, to compute at each model time step the turbulent air/sea and air/sea-ice fluxes using the bulk formula proposed by Large and Yeager (2004). Downwelling short and long wave radiative fluxes and precipitation are also provided by ERAInterim. Monthly climatological runoff (Dai and Trenberth, 2002) is applied along the land mask edge. While biases in radiation and precipitation fields are inevitable, we find that the heat and freshwater budgets of the NEMO model are able to come into global balance with the ERAInterim forcing without further modifications being made (M. Valdivieso, personal communication), see also Haines et al. (2012).

\section{Description of numerical experiments}

The experiments described in the paper are summarised in Table 1. For ORCA1 experiments (CTL1 and ASSIM1) the initial conditions for temperature and salinity are derived from the World Ocean Atlas 2005 (WOA05) climatology (Boyer et al., 2006) with a cold start in January 1989 with no initial circulation. A control CTL1 experiment was run free through 1989-2008, while the ASSIM1 experiment assimilated hydrographic data as in Smith and Haines (2009), using the ENACT/ENSEMBLES EN3v2.1 data, (Ingleby and Huddleston, 2007). The assimilation run at $1 / 4^{\circ}$ resolution is designated UR025.3, and covers the period 1989-2008, also using ERAInterim forcing, but initiated from a previous ocean reanalysis from the same model which ended in December 2004, for details see Haines et al. (2012).

The data assimilation method of (Haines et al., 2006); Smith and Haines, 2009), previously implemented within NEMO, was used for the assimilation. Referred to as the $S(T)$ scheme this is a two-step sequential scheme for hydrographic data based on optimal interpolation. Temperature profiles $(T)$ are assimilated along with a salinity balancing increment (Troccoli and Haines, 1999) to maintain the model's water mass properties (i.e. temperature-salinity relationships) in the absence of salinity data. In the second step salinity profiles $(S)$ are assimilated along isotherms (i.e. $S(T)$, see Haines et al., 2006). With the $S(T)$ increments being spread along isotherms this means that corrections to a particular water mass do not influence adjacent water masses, 
Table 1. A description of experiments.

\begin{tabular}{ccl}
\hline No & Experiment & Description \\
\hline 1 & CTL1 & $\begin{array}{l}\text { Control simulation forced with ERAInterim and initialised } \\
\text { from 1989 from WOA05 climatology (ORCA1 model) }\end{array}$ \\
2 & ASSIM1 & $\begin{array}{l}\text { Initialised and forced as CTL1 but with EN3 data } \\
\text { assimilation (ORCA1 model) }\end{array}$ \\
3 & UR025.3 & $\begin{array}{l}14^{\circ} \text { NEMO simulation with EN3 data assimilation forced } \\
\text { with ERAInterim atmospheric forcing. The initial ocean } \\
\text { and sea ice states are taken from previous ocean } \\
\text { reanalysis (Haines et al., 2012) }\end{array}$ \\
& &
\end{tabular}

This table gives a definition of all the experiments used in this paper.
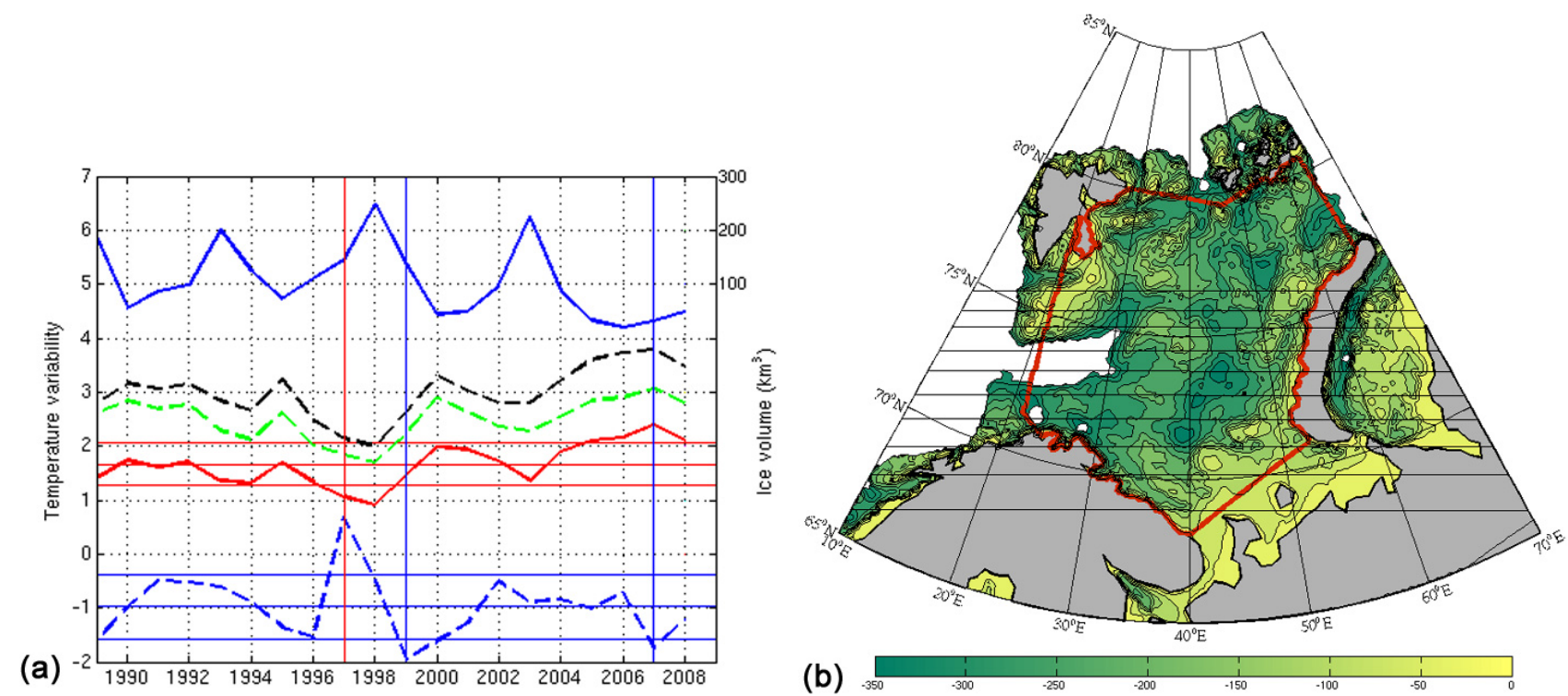

Fig. 1. (a) Annual top $200 \mathrm{~m}$ averaged temperature from CTL1 (dashed green), ASSIM1 (dashed black) and UR025.3 (red), and annual UR025.3 sea ice volume (solid blue) in the Barents Sea. NINO3-index minus 1 is shown by dashed blue line. Vertical lines show the beginning of warm (red) and cold (blue) ENSO events and horizontal lines - mean values plus and minis standard deviations (for curves corresponding to the same colours); (b) red line shows the region of the Barents Sea used for calculation of mean values. This panel also represents bathymetry in metres with units shown by the colourbar.

which may have uncorrelated errors. The scheme has been thoroughly tested and is used as part of the ECMWF system 3 ocean reanalysis, Balmaseda et al. (2008). The assimilation increments are calculated using a First Guess at Appropriate Time every 5 days ( 73 cycles per year) and then, following Bloom et al. (1996), an incremental analysis update method is used to add these increments evenly over the subsequent day.

Conventional spatial covariance scales defined in Carton et al. (2000) were used to spread out the increments to be made to the model $T$ and $S$ properties around the region where observation-model differences are detected. These scales were determined by Carton et al. (2000) by comparing anomaly decorrelation scales from pairs of in situ temperature observations (the zonal length scale varies from $450 \mathrm{~km}$ at the equator to $375 \mathrm{~km}$ in mid-latitudes, and the meridional length scale varies from $250 \mathrm{~km}$ at the equator to $375 \mathrm{~km}$ in mid-latitudes).

Since the 1989-2008 period is too short to include many ENSO events, we have also used the G70 1958-2004 simulation implemented by the DRAKKAR group (2007). This global simulation was driven without data assimilation over the whole 1958-2004 period by the hybrid interannual forcing DFS3 described in detail in Brodeau et al. (2010). This G70 run has many similar characteristics and variability to the UR025.3 run although the top mean $200 \mathrm{~m}$ temperature in the Barents Sea is consistently about $1{ }^{\circ} \mathrm{C}$ higher, and the Atlantic volume inflow about $10 \%$ lower than from UR025.3. 

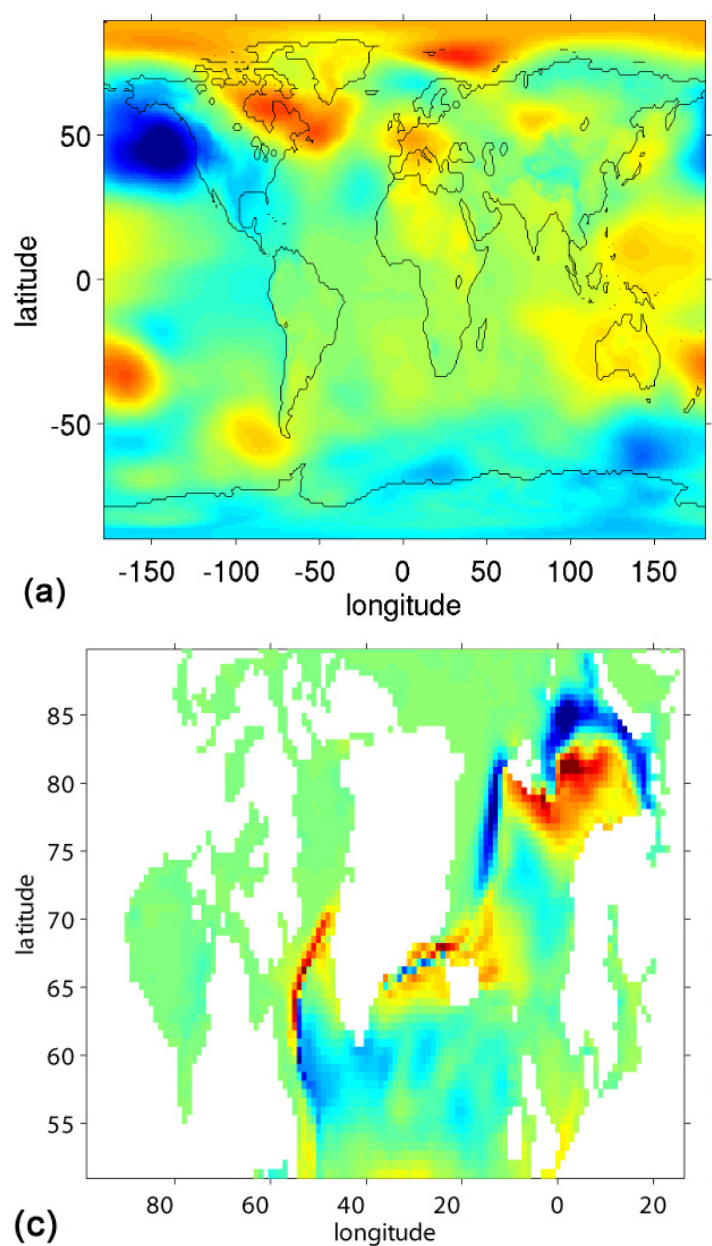
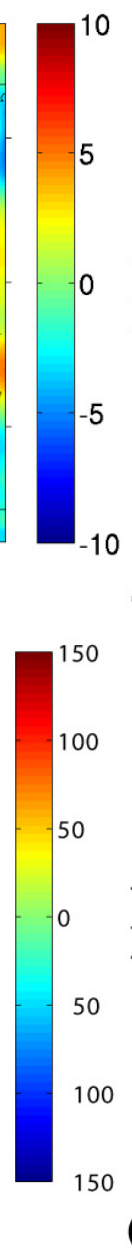
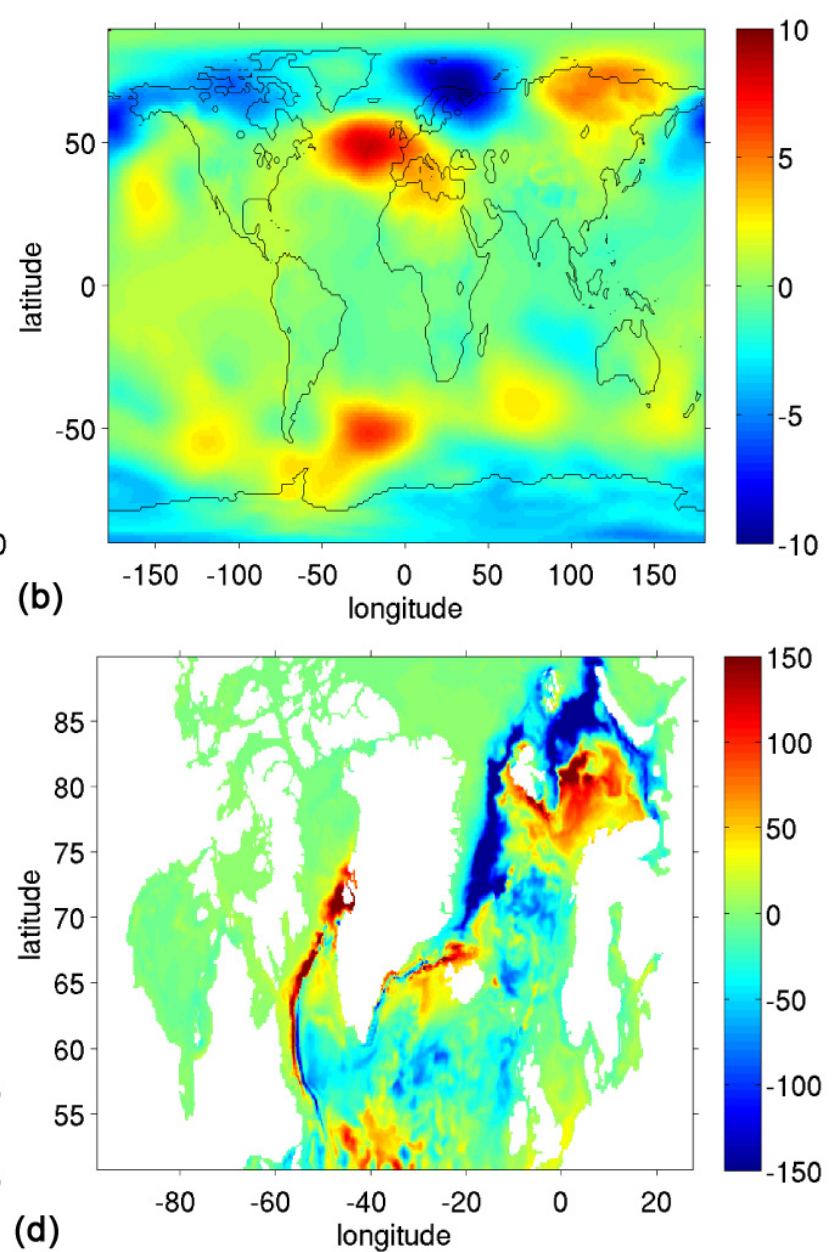

Fig. 2. Sea level pressure anomaly (in HPa) for January-March (JFM) of 1998 (a) and 2000 (b) after onsets of warm and cold ENSO events, respectively; net surface heat flux difference (in $\mathrm{W} \mathrm{m}^{-2}$ ) between 2000 and 1998 averaged for January-March period according to CTL1 (c) and UR025.3 (d) runs. The positive sign corresponds to the heat flux into the ocean.

\section{Interannual variability in the Barents Sea during ENSO events}

Figure 1a shows the top $200 \mathrm{~m}$ annual averaged temperatures in the region of the Barents Sea (Fig. 1b) from 3 different model experiments (black, green and red lines). Also shown are the sea ice volume from the UR025.3 experiment and the NINO3 index (the sea surface temperature in the region of the tropical Pacific $5^{\circ} \mathrm{S}-5^{\circ} \mathrm{N} ; 150-90^{\circ} \mathrm{W}$, http://www.cpc. ncep.noaa.gov/data/indices/).

During 1989-2008, according to NINO3 index, there were three strong ENSO events: a warm event in 1997-1998 and two cold events in 1999-2000 and 2007. During the warm ENSO in 1997-1998, the annual mean model temperatures in the top $200 \mathrm{~m}$ of the Barents Sea clearly decrease (by about $0.8^{\circ} \mathrm{C}$ over the next year) for all model runs, and a higher sea ice volume in UR025.3 is also clear. In contrast in 1999-2000 and 2007-2008, the model shows higher than normal annual mean temperatures in the Barents Sea, of $\sim 0.7^{\circ} \mathrm{C}$, and lower sea ice volumes. While these only represent a small number of events, we can take them as case studies for the local changes in the Barents Sea heat budget that accompany the changes in regional atmospheric forcing in these ENSO periods. These cool and warm Barents Sea events also appear to last over a 2-yr period with the maximum change in sea ice volume being observed in the second year.

Temperature variability from the $1^{\circ}$ and $1 / 4^{\circ}$ models look similar; however, the $1^{\circ}$ models overestimate the average temperature when compared to observations (see, e.g. Smedsrud et al., 2010), with the $1^{\circ}$ assimilation giving the highest temperatures. Both the $1^{\circ}$ models CTL1 ( $\left.3.8 \mathrm{~Sv}\right)$ and ASSIM1 (3.9 Sv) also overestimate the volume inflow into the Barents Sea compared to inverse model results $(3.5 \mathrm{~Sv}$; Tsubouchi et al., 2012) which, as we will show later, is the dominant component in the total heat balance of the Barents Sea. Probably, this explains the higher Barents Sea temperatures obtained by the $1^{\circ}$ model compared to UR025.3. The higher model resolution in UR025.3 produces the best estimation of 

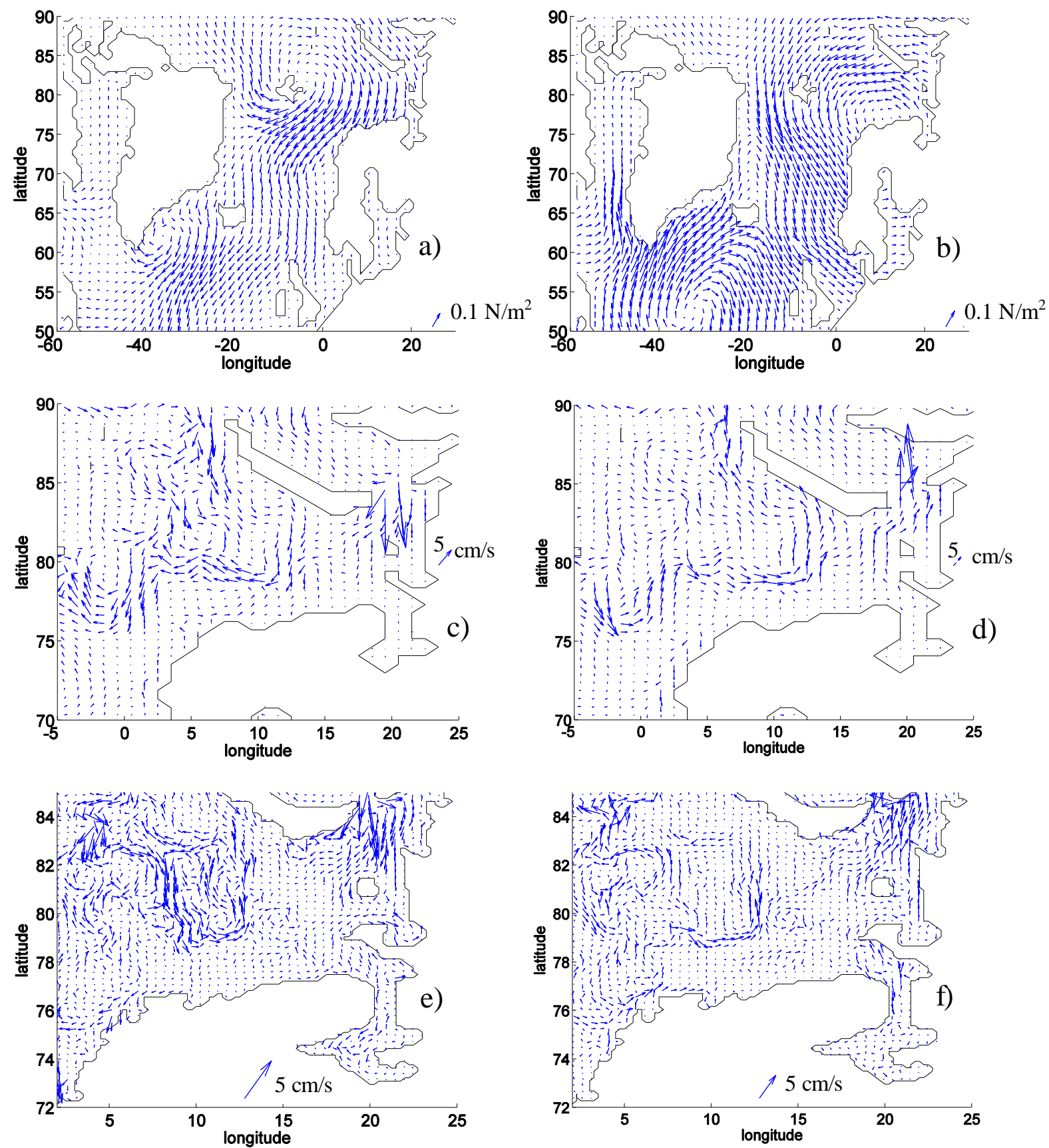

Fig. 3. (a, b) Winter (JFM) anomalies of wind stress over the North Atlantic and the Barents Sea in 1998 (a) and 2000 (b) after warm and cold ENSO events, respectively, and these (c, e) of ocean velocity, averaged for the top $200 \mathrm{~m}$ in the Barents Sea in 1998; (d-f) is the velocity vector differences between 2000 and 1998 averaged for the top $200 \mathrm{~m}$ in the Barents Sea; (c, d) is the experiment CTL1; (e, f) is the UR025.3 run. All anomalies are taken relative to the 1989-2008 mean.

the Barents Sea inflow (3.4 Sv) and therefore has more realistic upper ocean temperatures. However, the variability in monthly mean Barents Sea temperatures and Atlantic volume inflow does not substantially depend on model resolution (the standard deviation of annual mean temperatures is $\sim 0.4^{\circ} \mathrm{C}$ for the CTL1 and UR025.3 experiments and $\sim 0.5^{\circ} \mathrm{C}$ for AS-
SIM1) and is probably controlled directly by the wind forcing.

Figure 2 shows mean January-February-March (JFM) sea level pressure anomalies in 1998 (after the warm ENSO, (a)) and in 2008 (after the cold ENSO, (b)) from ERA-Interim. During JFM 1998 global atmospheric teleconnections lead to higher atmospheric pressure (Fig. 2a), and hence lower 


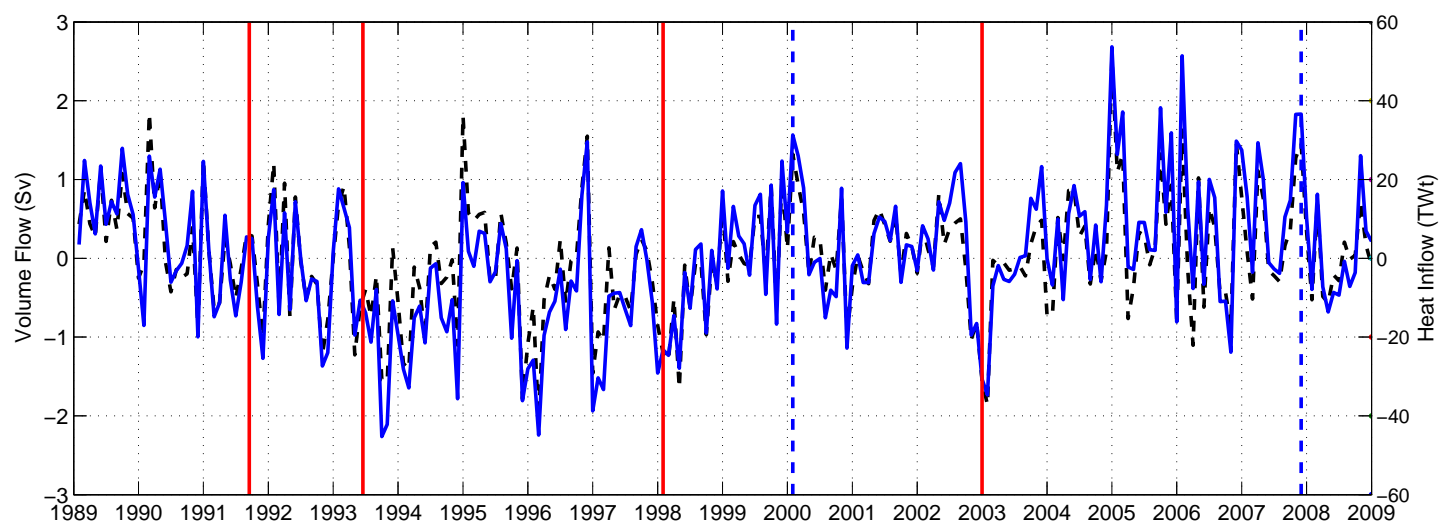

Fig. 4. Monthly UR025.3 anomalies of volume (dashed black line) and heat inflow into the Barents Sea (solid blue line) after removing seasonal cycle. Vertical lines show correspondence between warm (solid red) and cold (dashed blue) ENSO events and variability of heat transport into the Barents Sea from the North Atlantic.

air temperatures over the Barents Sea, while during JFM 2000 lower atmospheric pressure (Fig. 2b) lead to warmer air temperatures over the Barents Sea. These conditions lead to higher than averaged over 1989-2008 period heat loss over the Barents Sea in 1998 and lower heat losses in 2000 in all the model runs (e.g. Fig. 2c-d). Figure $2 \mathrm{c}-\mathrm{d}$ also shows the higher heat loss in the northern and northeastern Barents Sea during 2000 due to the ice edge displacement towards higher latitudes.

Figure 3a-b shows wind stress anomalies for JanuaryMarch 1998 and 2000 over the North Atlantic and the Barents Sea. This leads to a change in the Barents Sea mean currents. Figure 3c, e shows the top $200 \mathrm{~m}$ averaged current velocity anomaly from the CTL1 (c) and UR025.3 (e) experiments for January-March of 1998, after the warm ENSO event. Figure $3 \mathrm{~d}$, $\mathrm{f}$ is the velocity vector differences between 2000 and 1998 averaged for the top $200 \mathrm{~m}$ in the Barents Sea ((d) is the experiment CTL1 and (f) is the UR025.3 run). Both in the ORCA1 and ORCA025 runs under normal conditions along the Scandinavian peninsula there is a warm current entering the Barents Sea from the North Atlantic, however in JFM 1998 this current is much weaker, which therefore decreases the heat entering the Barents Sea from the North Atlantic. The flow through the Kara Gate (the strait between Vaygach and Novaya Zemlya) reverses direction from 2000 to 1998. This also leads to colder conditions in 1998: the transport of the warm North Atlantic water is decreasing while more cold waters from the Kara Sea are entering the Barents Sea. The NEMO model results agree with those obtained with finer space resolution modelling by Semenov and Chvelev (1996) and Sidorova and Shcherbinin (2009, 2011). They have shown that in the period of warm ENSO events the inflow of water from the North Atlantic into the Barents Sea is small, but there is an intensive inflow of cold waters with low salinity from the central Arctic ocean and from Kara Sea (see Fig. 3d, f).

Figure 4 shows the monthly anomalies of volume and heat inflow into the Barents Sea after removing the seasonal cycle (from the UR025.3 experiment). The monthly mean oceanic heat fluxes were calculated by averaging 5 day mean model fields of the product of the velocity and temperature, using a reference temperature of $0^{\circ} \mathrm{C}$. We clearly see that there is high correlation between volume and heat inflow in the Barents Sea, and we will show that this is the critical variability for controlling interannual changes in Barents Sea heat content. Thus we see that the change in atmospheric circulation can lead to changes in both surface heat loss over the Barents Sea and heat entering from the North Atlantic. The relative importance of these mechanisms is discussed in the next section.

\section{Heat budget variability in the Barents Sea}

Normalised seasonal cycle variability over 1989-2008 from the UR025.3 experiment is shown for the Barents Sea heat budget terms along with vertical structure, in Fig. 5. Heat is transported into the Barents Sea throughout the year but particularly in late autumn to early winter (black, peaking in December with a minimum in May) by ocean currents from the North Atlantic. In summer the net surface heat flux (red line) is controlled by shortwave radiation that adds heat to the Barents Sea (peaking in June-July) and heat is lost by latent, sensible and long wave radiation in winter (see, e.g. Smedsrud et al., 2010). The Barents Sea total heat content (green, the top $200 \mathrm{~m}$ mean temperature) shows every sign of being controlled primarily by the surface shortwave cycle, being $90^{\circ}$ out of phase with the surface forcing. 


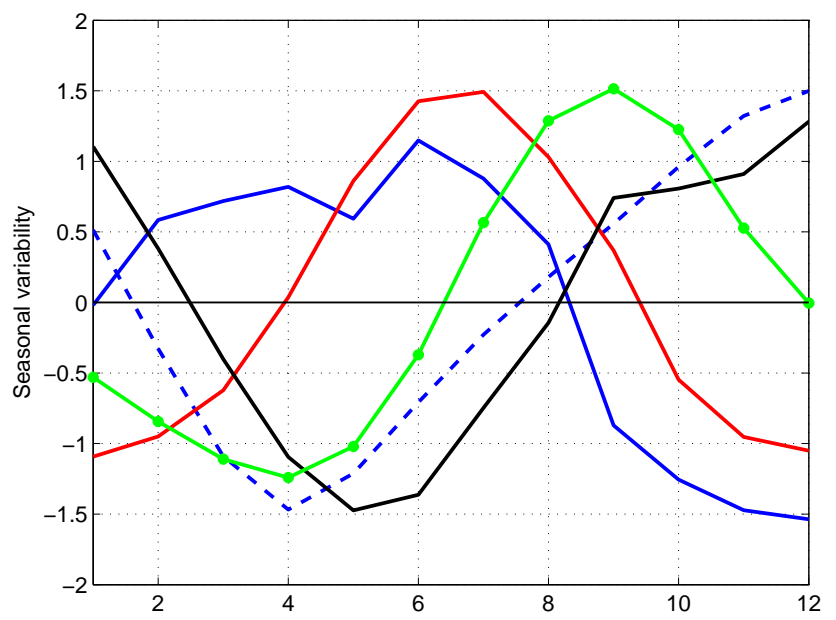

Fig. 5. Normalised seasonal cycle (to have zero mean and a standard deviation of one, mean and std dev of the original time series are given) of the depth of $1^{\circ} \mathrm{C}$ isotherm (solid blue line, mean and std dev are $261 \pm 79 \mathrm{~m}$ ), the minimal temperature value in the deep 130-320 m layer (dashed blue, mean and std dev are $1.48 \pm 0.40^{\circ} \mathrm{C}$ ); the top $200 \mathrm{~m}$ averaged Barents Sea temperature (green, mean and std dev are $1.66 \pm 0.95^{\circ} \mathrm{C}$ ), the Barents Sea heat inflow (black, mean and std dev are $86.5 \pm 21.0 \mathrm{TW}$ ) and the net surface flux (red, mean and std dev are $-98.6 \pm 158.8 \mathrm{~W} \mathrm{~m}^{-2}$ ).

The heat content of the deeper layers, and the deep vertical structure of the Barents Sea is however more clearly related to the heat inflow from the Atlantic, with the depth of the $1^{\circ} \mathrm{C}$ isotherm (blue) remaining shallow from February through June and only deepening substantially after August when the ocean inflow from the North Atlantic (black) reaches its peak. The minimum temperature in the $130-320 \mathrm{~m}$ layer (dashed blue) also reflects the impact of the Barents Sea heat inflow: the dashed blue and black lines vary almost in phase with each other. The January-April decrease of the Barents Sea heat inflow, accompanied by surface heat losses, leads to a cooling of this deep ocean layer.

The spring and summer warming due to absorption of incoming short wave radiation forms a sharp and shallow pycnocline in the Barents Sea. It substantially impedes heat- and salt-exchanges between deep and upper layers. As a result the $1{ }^{\circ} \mathrm{C}$ isotherm is shallower (in comparison with its mean value) until August since the heat transport from the North Atlantic is low during this time. Only after August does the $1{ }^{\circ} \mathrm{C}$ isotherm deepen reflecting the increase of the Barents Sea heat inflow.

Figure 6 uses correlations to show which months contribute to the annual mean variability for different components of the Barents sea heat budget. For surface heat fluxes (green line) only the winter months (from January to March, when the main cooling occurs) and again in July-August (when maximal ocean warming is observed) can influence interannual variability. For the heat transport (red) there is similar correlation for all months, suggesting that anomalous

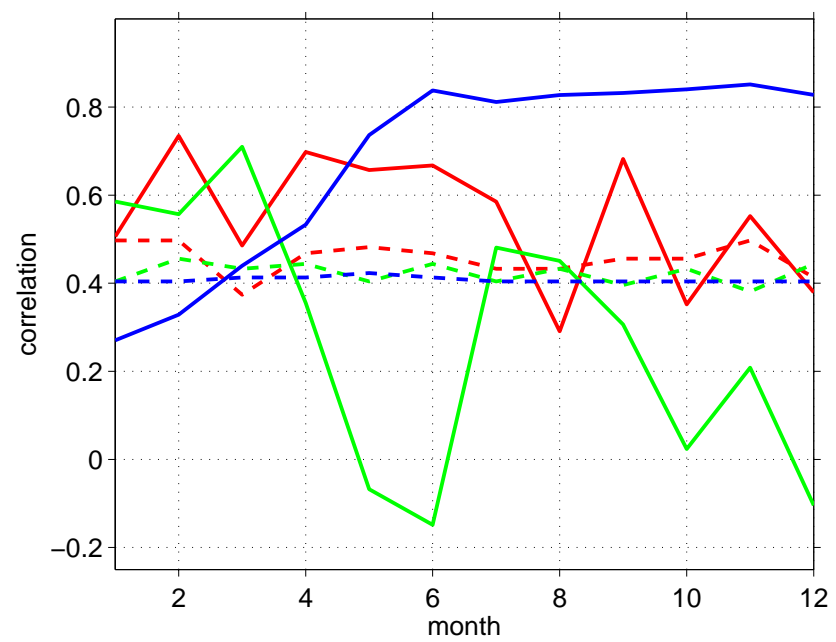

Fig. 6. Correlations annual NINO3-index (blue), the heat due to the Barents Sea inflow (red) and net surface heat flux (green) time series with their time series corresponding to each month; dashed lines denote corresponding statistical significance at the $95 \%$ level.

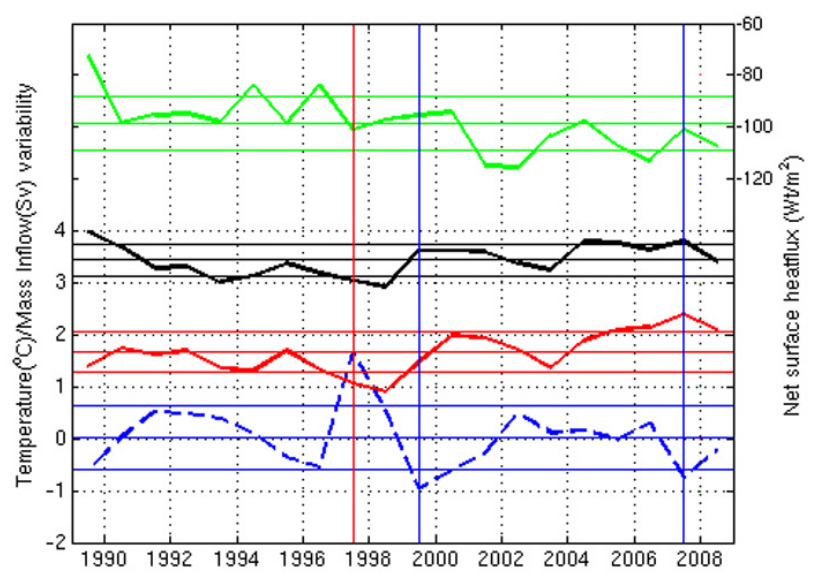

Fig. 7. Annual top $200 \mathrm{~m}$ averaged temperature (red) together with the Barents Sea inflow (black line) and net surface heat loss (green) from UR025.3 experiment. NINO3-index is shown by dashed blue line. Vertical lines show warm (red) and cold (blue) ENSO events and horizontal lines - plus and minis standard deviations (for curves corresponding to the same colours).

heat transports can be spread over the whole year. Figure 7 looks at the correspondence between interannual variability in Barents Sea mean temperatures, the surface heat fluxes, and the heat inflow from the Atlantic during the ERAInterim period from the UR025.3 run. There is a close correspondence between cold (warm) conditions in the Barents Sea (red) and the lower (higher) Barents Sea inflow (black) in Fig. 7. A high correlation between the inflow and the Barents Sea temperature has also been found by previous authors (e.g. Loeng et al., 1997; Dickson et al., 2000; Furevik, 2001). 


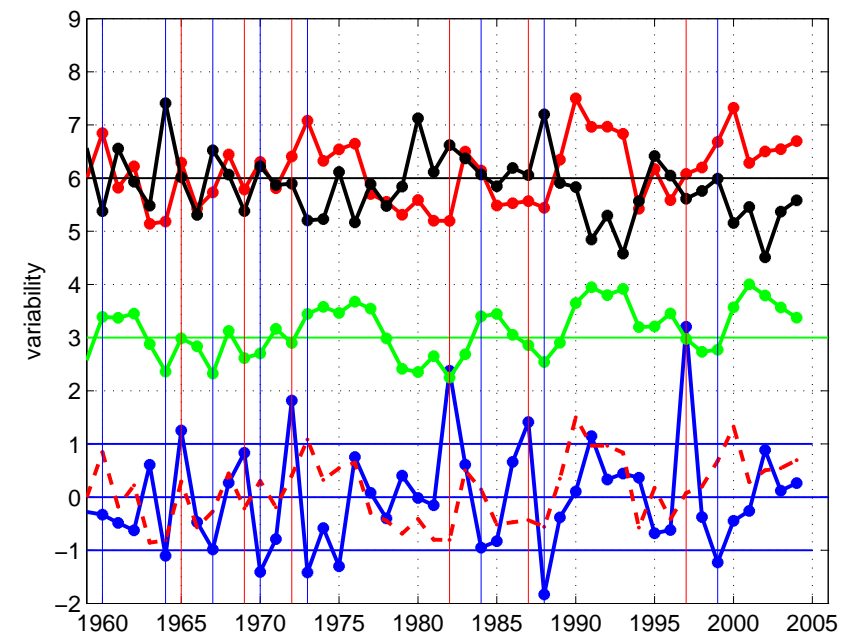

Fig. 8. Normalised April-December (for current year) mean time series of NINO3-index (blue); April/a current year-March/a subsequent year mean of the Barents Sea heat inflow (red), the net surface flux (black) and the averaged on the Barents Sea heat content (green) from G70 run. See text for details. Vertical lines show maxima (red) and minima (blue) NINO3-index (more its standard deviation, thin blue horizontal lines). For reading convenience the Barents Sea heat inflow is shown additionally by dashed red line (the same as a solid red one) together with NINO3 index curve.

However, there is no obvious connection between the Barents Sea temperature and the net Barents Sea annual mean surface heat flux (green). It can also be seen that strong ENSO events (blue dashed) are negatively correlated with the Barents Sea inflow (with coefficient of -0.6 and significant with a probability of $95 \%$ determined through the effective number of degrees of freedom following Bretherton et al., 1999). The correlation between the annual Barents Sea top $200 \mathrm{~m}$ temperature and heat inflow time series is about $C_{\mathrm{TF}} \approx 0.7$ and approximately the same correlation coefficient is obtained when the Barents Sea inflow variability leads the temperature changes by $1 \mathrm{yr}$. On the other hand, the annual net Barents Sea surface heat flux variability lags the annual Barents Sea temperature variability by $1 \mathrm{yr}$, with a statistically significant negative correlation coefficient of $C_{\mathrm{TH}} \approx-0.6$ suggesting that surface heat loss is responding to, rather than causing, Barents Sea anomalies. Similar correlations of the annual Barents Sea temperature with the Barents Sea inflow and the net surface heat flux time series are also obtained for the pure simulation from G70 model data: $C_{\mathrm{TF}} \approx 0.7$ and $C_{\mathrm{TH}} \approx-0.5$.

Figure 8 presents the normalised April-December mean time series of NINO3-index (blue), and G70 Barents Sea heat content (green) and heat inflow (red) obtained by averaging monthly data from April to March of the subsequent year. These periods were selected because the main teleconnections with ENSO (with maximal development in December, e.g. see Caviedes, 2001) are observed at the beginning of the
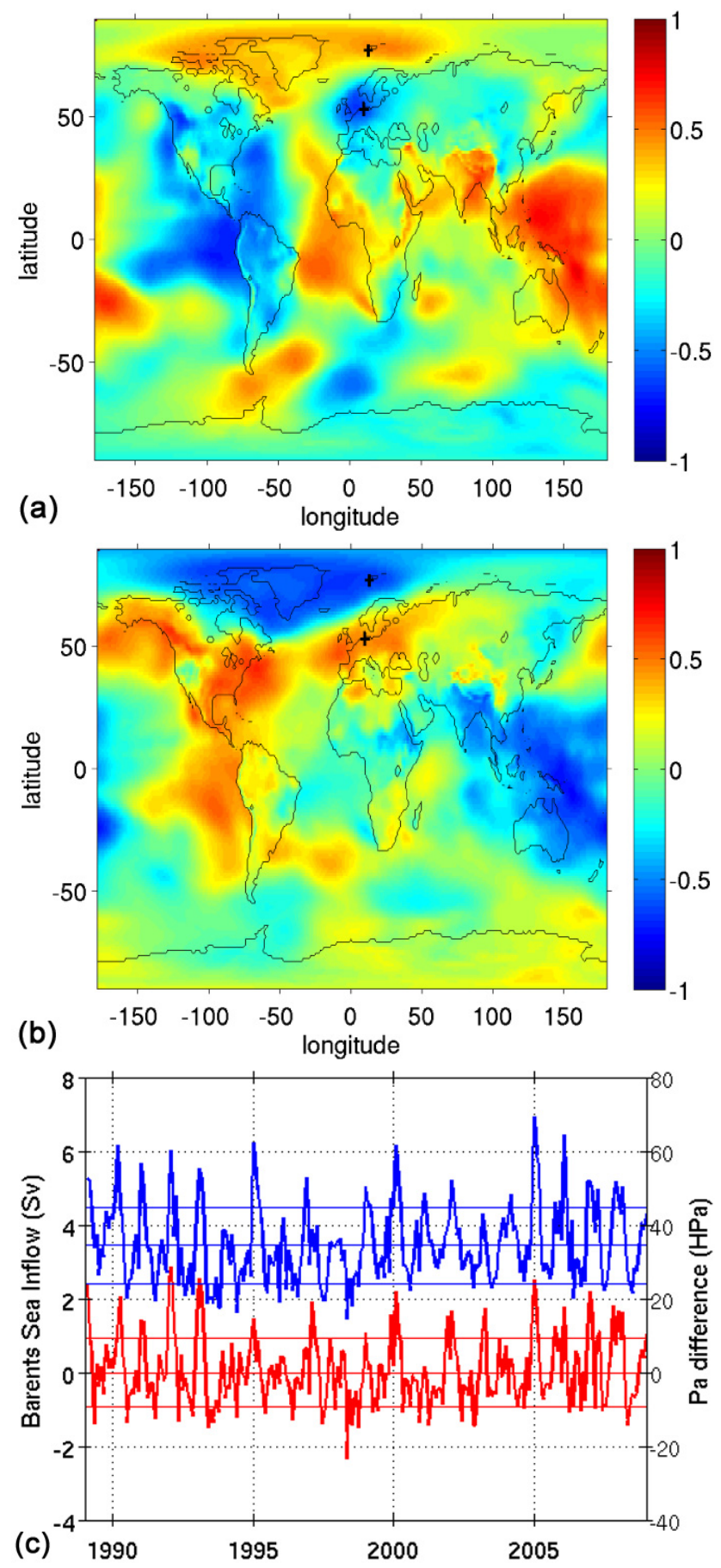

Fig. 9. 1989-2008 correlations of mean sea level pressure averaged for the period from April to July with April NINO3-index (a) and (b) with the averaged for the same period Barents Sea inflow; (c) the Barents Sea inflow (blue) and (red) pressure differences between Western Europe and Spitsbergen (the regions are marked by black crosses on $(\mathbf{a}-\mathbf{b})$.

following year. The black line shows the similarly calculated time series of the net surface flux, but scaled by the standard deviation of the Barents Sea heat inflow, so as to obtain these 


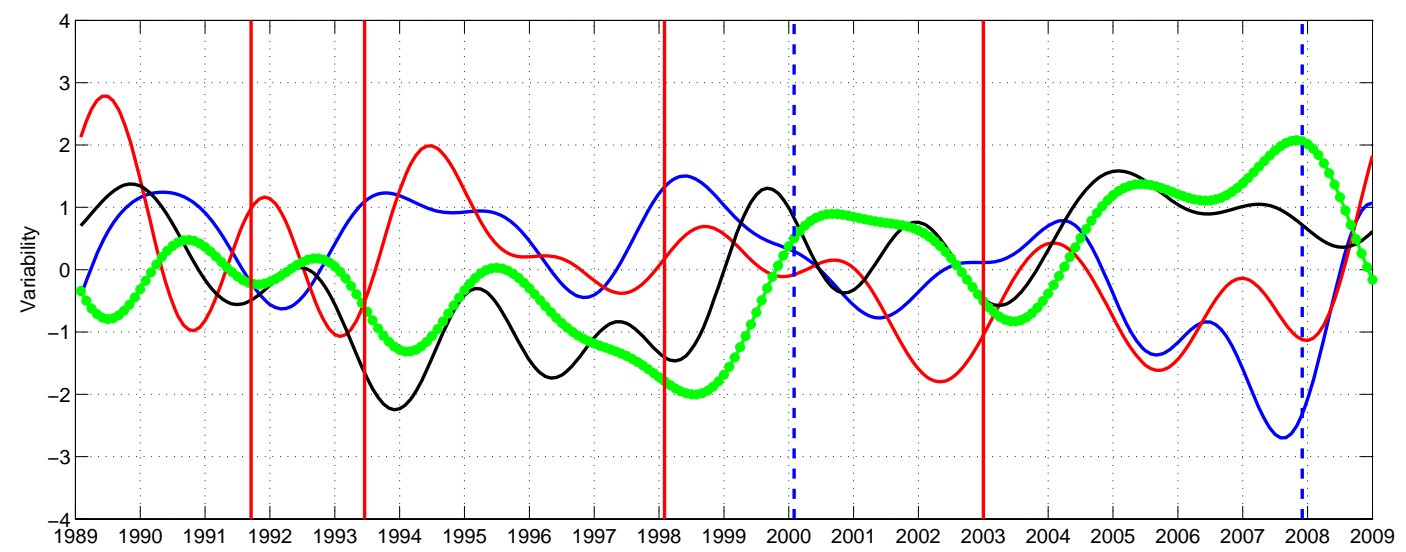

Fig. 10. Normalised on their standard deviations anomalies (after subtraction of seasonal cycle) of the depth of $1^{\circ} \mathrm{C}$ isotherm (blue), the top $200 \mathrm{~m}$ averaged Barents Sea temperature (green), the Barents Sea heat inflow (black) and the net surface flux (red).

two time series on the same scale. The anti-correlation of the Barents Sea heat content with the heat inflow at multi-annual timescales is clear.

Figure 8 also shows some clear correspondence between the NINO3-index and the mean temperature curve. Three of the 7 strong (more than 1 standard deviation) NINO3 peaks (1 warm: 1982 and 2 cold: 1973 and 1984) show an immediate inverse temperature relation in the Barents Sea in the same year. In the other 4 ENSO events, two warm (1987 and 1997) and two cold (1988, 1999), the NINO3-index leads the Barents Sea inverse temperature peaks by $1 \mathrm{yr}$ for the warm, and $2 \mathrm{yr}$ for the cold ENSO events, respectively. The correlation coefficient between NINO3 index and the top $200 \mathrm{~m}$ mean Barents Sea temperature is -0.5 when ENSO leads the Barents Sea temperature variability by $1 \mathrm{yr}$. The ENSO events before 1972 were weaker and occurred more frequently (reversing index every $1-2 \mathrm{yr}$ ), and perhaps therefore did not lead to substantial Barents Sea temperature variability, e.g. the cooling due to previous ENSO being compensated by warming by the subsequent ENSO event.

For 5 cases (1982, 1987 - warm, and 1973, 1988, 1999 cold) the Barents Sea heat content anomalies clearly correspond to heat inflow extrema. For 2 cases (1984 and 1997) a better relationship with Barents Sea heat content is found but not with heat inflow (at least based on our model). The warm 1997 ENSO event results in the Barents Sea cooling during the following year through higher the Barents Sea heat loss through it the surface. For the cold 1984 ENSO both the heat inflow and the net surface flux have close to averaged values. However this event occurs immediately after the strong warm ENSO in 1982-1983. Likely the interaction between the atmosphere and ocean during the period 19821983 could mean that the heat inflow and the net surface flux change in the same phase (Fig. 8), leading to higher Barents Sea temperatures in 1984.
Thus in more than $70 \%$ of cases (for $30 \mathrm{yr}$ period) a negative correlation between temperature and ENSO events is due to the Barents Sea heat inflow variability, although in some cases the net surface flux change at interannual scales also can have an impact on the heat balance. In our NEMO model the values of the Barents Sea heat content averaged from April to March of the subsequent year are positively correlated with a similar time series of the Barents Sea inflow (correlation coefficient $\sim 0.9$ ) and negatively correlated with the net surface flux (with correlation $\sim-0.9$ ). Also there is a negative correlation between the net surface flux and the Barents Sea inflow with coefficient of about -0.8 .

Figure 9 shows correlations between the April-July mean ERAInterim SLP and (a) the NINO3-index in April, and (b) the Barents Sea April-July mean inflow, for 1989-2008, calculated from UR025.3 model data. We used the NINO3index averaged for April as an early predictor for ENSO events and the annual mean NINO3-index strongly correlates with the monthly time series corresponding to each month from April to December (Fig. 6, blue line). The anticorrelations are clear to see and in particular Fig. 9b indicates stronger geostrophic winds blowing towards the Barents Sea driving the inflow. The Barents Sea inflow is also correlated with changes in the westerly winds across the North Atlantic, represented by pressure differences between northwestern Europe and Spitsbergen, $\Delta \mathrm{Pa}$, (the regions are marked by black crosses on Fig. 9a-b). Figure 9c shows monthly values of the Barents Sea inflow and the $\Delta \mathrm{Pa}$ time series. Correlation between the Barents Sea inflow and $\Delta \mathrm{Pa}$ is $\sim 0.8$ and statistically significant at the $95 \%$ level. There are some similarities with the results of Hughes and Stepanov (2004) who found correlations between the sea level variability in the northern polar seas and pressure differences between Greenland and southern Scandinavia (note that they used the NCEP reanalysis pressure distributions rather than ERAInterim). 
The above discussions show that heat storage in one year can influence the Barents Sea heat balance during the following year. This is explained by the dominant role of the Barents Sea inflow from the North Atlantic: cooling during cold winters is restricted by ice formation in the upper layers (i.e. when the temperature reaches freezing point the Barents Sea is covered by sea ice and it stops loosing heat). While in the deeper layers the heat supply from the North Atlantic (that reaches a maxim in winter, Fig. 5) can continue. In AprilJune Barents Sea inflow from the North Atlantic leads to accumulation of heat in the deeper layers and this can result in the formation of either positive or negative heat content anomalies before the next cold period. These anomalies then influence the heat lost during the next cold season: the warmer the temperature and the deeper the layer of this water, the greater can be the heat loss during the subsequent cold period.

Figure 10 shows time series of normalised anomalies (after subtraction of a seasonal cycle) of the depth of $1{ }^{\circ} \mathrm{C}$ isotherm (blue), the averaged Barents Sea temperature (green), the Barents Sea heat inflow (black) and the net surface heat flux (red), after applying a low-pass filter for periods longer than 24 months. We see that, if we discard the first few years allowing ocean model adjustment, the more heat inflow normally leads to deeper $1{ }^{\circ} \mathrm{C}$ isotherms, and vice versa. The warmer (colder) Barents Sea loses more (less) heat during the subsequent cold season (compare the green and red lines). If the Barents Sea inflow is high (black line), then the averaged temperature will be higher in the subsequent year (due to accumulation of heat from the North Atlantic), while a low value results in more cooling conditions in the current year. This explains the positive correlation between the April-March averaged Barents Sea inflow, and the top $200 \mathrm{~m}$ averaged Barents Sea temperature time series (0.9).

\section{Summary}

We have analysed results from ORCA1 $\left(1^{\circ}\right)$ and ORCA025 $\left(1 / 4^{\circ}\right)$ NEMO ocean models for the Barents Sea and have found that model results are in agreement with observational data in the Barents Sea along a meridian of $33^{\circ} 30^{\prime} \mathrm{E}$ between $70^{\circ} 30^{\prime}$ and $72^{\circ} 30^{\prime} \mathrm{N}$, showing negative correlation between ENSO events and water temperatures in the Barents Sea. During (or shortly after) strong warm ENSO events the annual mean ORCA025 model temperature in the Barents Sea decreases by about $0.8^{\circ} \mathrm{C}$, also resulting in a higher sea ice cover. While for cold ENSO events the model shows a lower sea ice cover, and higher annual mean water temperatures in the Barents Sea of about $0.7^{\circ} \mathrm{C}$. These values are in a good agreement with observed data (Byshev and Neiman, 2000; Byshev and Lebedev, 2000; Byshev et al., 2001; Byshev, 2003).

It is shown that the Barents Sea inflow is the main source of the Barents Sea heat content variability. During the period of April-July the heat transported from the North Atlantic can be accumulated by the Barents Sea, resulting in the formation of either positive or negative summer heat content anomalies that then influence the Barents Sea during the following cold season. In some years, about $30 \%$ of all model cases, the effects of heat exchange with the atmosphere can be a more dominant mechanism in an annual heat balance of the Barents Sea. This change depends substantially upon an ENSO event occurring in the preceding years.

Acknowledgements. Comments from an anonymous reviewer and Vladimir Byshev helped to significantly improve the manuscript. This work was supported by the NERC through the RAPID-Watch Valor and the NCEO projects.

Edited by: M. Hecht

\section{References}

Adcroft, A., Hill, C., and Marshall, J.: Representation of topography by shaved cells in a height coordinate ocean model, Mon. Weather Rev., 125, 2293-2315, 1997.

Balmaseda, M. A., Vidard, A., and Anderson, D. L. T.: The ECMWF ocean analysis system: ORAS3, Mon. Weather Rev., 136, 3018-3034. doi:10.1175/2008MWR2433.1, 2008.

Barnier, B. and the DRAKKAR Group: Eddy-permitting ocean circulation hindcasts of past decades, Clivar Exchanges, 12, 8-10, 2007.

Barnier, B., Madec, G., Penduff, T., Molines, J. M., Treguier, A. M., Le Sommer, J., Beckmann, A., Biastoch. A., Böning, C., Dengg, J., Derval, J., Durand, E., Gulev, S., Remy, E., Talandier, C., Theetten, S., Maltrud, M., McClean, J., and De Cuevas, B.: Impact of partial steps and momentum advection schemes in a global ocean circulation model at eddy-permitting resolution, Ocean Dynam., 56, 6543-567, doi:10.1007/s10236-006-0082-1, 2006.

Blanke, B. and Delecluse, P.: Variability of the Tropical Atlantic Ocean Simulated by a General Circulation Model with Two Different Mixed-Layer Physics, J. Phys. Oceanogr., 23, 1363-1388, 1993.

Bloom, S. C., Tacks, L. L., daSilva, A. M., and Ledvina, D.: Data assimilation using incremental analysis updates, Mon. Weather Rev., 124, 1256-1271, 1996.

Boyer, T. P., Garcia, H. E., Johnson, D. R., Locarnini, R. A., Mishonov, A. V., Pitcher, M. T., Baranova, O. K., and Smolyar, I. V.: World Ocean Database 2005, NOAA Atlas NESDIS 60, edited by: Levitus, S., 190 pp., US Gov. Print. Off.: Washington DC, 2006.

Bretherton, C. S., Widmann, M., Dymnikov, V. P., Wallace, J. M., and Blad, I.: The effective number of spatial degrees of freedom of a time-varying field, J. Climate, 12, 1990-2009, 1999.

Brodeau, L., Barnier, B., Penduff, T., Treguier, A.-M., and Gulev, S.: An ERA40 based atmospheric forcing for global ocean circulation models, Ocean Model., 31, 88-104, 2010.

Byshev, V. I.: Synoptical and large-scale variability of ocean and the atmosphere, Moscow, Nauka, 343pp., 2003 (in Russian). 
Byshev, V. I. and Lebedev, M. M.: Probalistic response of the atmosphere of the northern hemisphere to El Niño events, Oceanology, 40, 631-638, 2000.

Byshev, V. I. and Neiman, V. G.: Response of the Barents Sea to the El Niño Events, Dokl. Earth Sci., 373A, 1070-1073, 2000.

Byshev, V. I., Galerkin, L. I., Galerkina, N. L., Yu, Ivanov, A., and Fomin, L. M.: Cooling of the Barents Sea during the El Niño phenomenon in 1997-1998. Dokl. Earth Sci., 376, 110-113, 2001. Byshev, V. I., Galerkin, L. I., and Galerkina, N. L.: Thermohaline structure of the Barents Sea waters and its variability on the basis of the observations in 1997 and 1998, Oceanology, 42, Suppl. 1, S30-S46, 2002.

Carton, J. A., Chepurin, G., Cao, X., and Giese, B.: A simple ocean data assimilation analysis of the global upper ocean 1950-95, Part I: Methodology, J. Phys. Oceanogr., 30, 294-309, 2000.

Caviedes, C. N.: El Niño in History: Storming Through the Ages, University Press of Florida, 279 pp., 2001.

Coachman, L. K. and Aagaard, K.: Physical oceanography of Arctic and subarctic seas, Marine Geology and Oceanography of the Arctic Seas, edited by: Herman, E., Springer-Verlag, 1-72, 1974.

Dai, A. and Trenberth, K. E.: Estimates of freshwater discharge from continents: Latitudinal and seasonal variations, J. Hydrometeorol., 3, 660-687, 2002.

Dee, D. P. and Uppala, S.: Variational bias correction of satellite radiance data in the ERA-Interim reanalysis, Q. J. Roy. Meteor. Soc., 135, 1830-1841, 2009.

Dickson, R., Osborn, T., Hurrell, J., Meincke, J., Blindheim, J., Ådlandsvik, B., Vinje, T., Alekseev, G., and Maslowski, W.: The Arctic Ocean Response to the North Atlantic Oscillation, J. Climate, 13, 2671-2696, 2000.

DRAKKAR Group: Eddy-permitting ocean circulation hindcasts of past decades, Clivar Exchanges, 12, 8-10, 2007.

Fichefet, T. and Maqueda, M.: Sensitivity of a global sea ice model to the treatment of ice thermodynamics and dynamics, J. Geophys. Res., 102, 12609-12646, 1997.

Furevik, T.: Annual and interannual variability of Atlantic Water temperatures in the Norwegian Seas: 1980-1996, Deep-Sea Res., 48, 383-404, 2001.

Goose, H. and Fichefet, T.:Importance of ice-ocean interactions for the global ocean circulation: A model study. J. Geophys. Res., 104, 23337-23355, 1999.

Haines, K., Blower, J., Drecourt, J. P., Liu, C., Vidard, A., Astin, I., and Zhou, X.: Salinity assimilation using $\mathrm{S}(\mathrm{T})$ relationships, Mon. Weather Rev., 134, 759-771, 2006.

Haines, K., Valdivieso, M., Zuo, H., and Stepanov, V. N.: Transports and budgets in a $1 / 4^{\circ}$ global ocean reanalysis 1989-2010, Ocean Sci., 8, 333-344, doi:10.5194/os-8-333-2012, 2012.

Hughes, C. W. and Stepanov, V. N.: Ocean dynamics associated with rapid $\mathbf{J} 2$ fluctuations: Importance of circumpolar modes and identification of a coherent Arctic mode, J. Geophys. Res., 109, 12pp.,doi:10.1029/2003JC002176, 2004.

Ingleby, B. and Huddleston, M.: Quality control of ocean temperature and salinity profiles - Historical and real-time data, J. Marine Syst., 65, 158-175, 2007.

Large, W. G. and Yeager, S. G.: Diurnal to decadal global forcing for ocean and sea-ice models: The data sets and flux climatologies, Technical Report TN-460+STR, NCAR, 105 pp., 2004.

Lau, N.-C., Leetmaa, A., Nath, M. J., and Wang, H.-L.: Influence of ENSO-induced Indo-Western Pacific SST anomalies on ex- tratropical atmospheric variability during the boreal summer, J. Climate, 18, 2922-2942, 2005.

Lique, C., Treguier, A. M., Scheinert, M., and Penduff, T.: A model-based study of ice and freshwater transport variability along both sides of Greenland, Clim. Dyn., 20, 685-705, doi:10.1007/s00382-008-0510-7, 2009.

Lique, C., Treguier, A. M., Blanke, B., and Grima, N.: On the origins of water masses exported along both sides of Greenland: a Lagrangian model analysis, J. Geophys. Res., 115, C05019, doi:10.1029/2009JC005316, 2010.

Loeng, H., Ozhigin, V., and Ådlandsvik, B.: Water fluxes through the Barents Sea, ICES J. Marine Sci., 54, 310-317, 1997.

Madec, G.: NEMO reference manual, ocean dynamics component: NEMO-OPA. Preliminary version, Note du Pole de modélisation, Institut Pierre-Simon Laplace (IPSL), France, No. 27. ISSN No. 1288-1619, 2008.

Madec, G., Delecluse, P., Imbard, M., and Levy, C.:OPA 8.1 general circulation model reference manual, Notes de l'IPSL, University P. et M. Curie, B102 T15-E5, Paris, 11, 91pp., 1998.

Mokhov, I. I. and Smirnov, D. A.: El Niño-Southern Oscillation drives North Atlantic Oscillation as revealed with nonlinear techniques from climatic indices Geophys. Res. Lett., 33, L03708, doi:10.1029/2005GL024557, 2006.

Mosby, H.: Water, salt and heat balance of the North Polar Sea and the of the Norwegian Sea, Geofysiske Publikasjoner (Geophysica Norvegica), 24, 289-313, 1962.

Müller, W. A. and Roecker, E.: ENSO impact on midlatitude circulation patterns in future climate change projections, Geophys. Res. Lett., 33, L05711, doi:10.1029/2005GL025032, 2006.

Nicholls, N., Baek, H.-J., Gosai, A., Chambers, L. E., Choi, Y., Collins, D., Della-Marta, P. M., Griffiths, G. M., Haylock, M. R., Iga, N., Lata, R., Maitrepierre, L., Manton, M. J., Nakamigawa, H., Ouprasitwong, N., Solofa, D., Tahani, L., Thuy, D. T., Tibig, L., Trewin, B., Vediapan, K., and Zhai, P.: The El Niño-Southern Oscillation and daily temperature extremes in east Asia and the west Pacific, Geophys. Res. Lett., 32, L16714, doi:10.1029/2005GL022621, 2005.

Penduff, T., Le Sommer, J., Barnier, B., Treguier, A.-M., Molines, J.-M., and Madec, G.: Influence of numerical schemes on current-topography interactions in $1 / 4^{\circ}$ global ocean simulations, Ocean Sci., 3, 509-524, doi:10.5194/os-3-509-2007, 2007.

Penduff, T., Juza, M., Brodeau, L., Smith, G. C., Barnier, B., Molines, J.-M., Treguier, A.-M., and Madec, G.: Impact of global ocean model resolution on sea-level variability with emphasis on interannual time scales, Ocean Sci., 6, 269-284, doi:10.5194/os6-269-2010, 2009.

Semenov, G. A. and Chvelev, S. V.: Numerical investigation interannual variability of the Barents sea circulation water in the summer, Oceanology, 36, 498-511, 1996.

Serreze, M., Barrett, A., Slater, A., Steele, M., Zhang, J., and Trenberth, K.: The large-scale energy budget of the Arctic, J. Geophys. Res., 112, D11122, doi:10.1029/2006JD008230, 2007.

Sidorova, A. N. and Shcherbinin, A. D.: Barents Sea Hydrodynamics Change during the El-Niño Event, Doklady Earth Sciences, 429A, 1562-1566, 2009.

Sidorova, A. N. and Shcherbinin, A. D.: Hydrometeorological conditions in the Barents Sea during El Niño of 1997-1998, Russ. Meteorol. Hydrol., 36, 185-192, doi:10.3103/S1068373911030058, 2011. 
Signorini, S. R and McClain, C. R.: Environmental factors controlling the Barents Sea spring-summer phytoplankton blooms, Geophys. Res. Lett., 36, L10604, doi:10.1029/2009GL037695, 2009. Simmons A., Uppala, S., Dee, D., and Kobayashi, S.: ERA-Interim: New ECMWF reanalysis products from 1989 onwards, ECMWF Newsletter, 110, 25-35, 2007.

Smedsrud, L. H., Ingvaldsen, R., Nilsen, J. E. Ø., and Skagseth, Ø.: Heat in the Barents Sea: transport, storage, and surface fluxes, Ocean Sci., 6, 219-234, doi:10.5194/os-6-219-2010, 2010.

Smith, G. C. and Haines, K.: Evaluation of the S(T) assimilation method with the Argo dataset, Q. J. Roy. Meteor. Soc., 135, 739756, 2009.

Terziev, F. S. (Ed.): The Seas of the USSR. Hydrometeorology and Hydrochemistry of the Seas, in: The Barents Sea, Issue 1: Hydrometeorological Conditions, Leningrad: Gidrometeoizdat, 1990 (in Russian).
Troccoli, A. and Haines, K.: Use of the temperature - salinity relation in a data assimilation context, J. Atmos. Ocean Tech., 16, 2011-2025, 1999.

Tsubouchi, T., Bacon, S., Naveira Garabato, A. C., Aksenov, Y. Laxon, S., Fahrbach, E., Beszczynska-Möller, A., Hansen, E., Lee, C. M., and Ingvaldsen, R. B.: The Arctic Ocean in summer: boundary fluxes and water mass transformation. J. Geophys. Res., 117, C01024, doi:10.1029/2011JC007174, 2012.

US Department of Commerce, National Oceanic and Atmospheric Administration, National Geophysical Data Center: 2-minute Gridded Global Relief Data (ETOPO2v2), 2006.

Zuo, H., Mugford, R. I., Haines, K., and Smith, G. C.: Assimilation impacts on Arctic Ocean circulation, heat and freshwater budgets, Ocean Model., 40, 147-163, 2011. 